\title{
Uncomfortable Heroes... Comparing thoughts about Latvian Riflemen and SS-Legionnaires in Latvian Memorial Culture 1920-2017
}

\section{T. Plath}

For citation: Plath T. Uncomfortable Heroes... Comparing thoughts about Latvian Riflemen and SS-Legionnaires in Latvian Memorial Culture 1920-2017. Vestnik of Saint Petersburg University. History, 2018, vol. 63, issue 2, pp. 479-487. https://doi.org/10.21638/11701/spbu02.2018.210

In both World Wars of the $20^{\text {th }}$ century a significant proportion of the male population of Latvia participated in special Latvian units in warfare - the Latvian Riflemen in World War I and the SS-Legionnaires in World War II. The article attempts to compare the representation of these units in Latvian memorial culture, with a special focus on the historiography. Although both units played an integral part in Latvian History in the $20^{\text {th }}$ century, a comparable approach hasn't been undertaken yet, which seems to be indispensable because perceived together they almost perfectly reflect radical turns in Latvian History in the previous century. Firstly, and naturally for a military unit, there is a narrative of brave and bold fighters for a national cause best exemplified in the issues of the Christmas Battles or the Volkhov Battles. Secondly, and to a certain extent contrary to the first aspect, there is an issue of traitors and collaborators, such as Red Riflemen or German cannon fodder. Finally, they represent an extraordinarily sharp and rapid shift from the Latvians depicted as anti-German and leftwing socialist Revolutionaries at the beginning of the century to Nazi rightwing henchmen during the second half of the century until today.

Keywords: history of Latvia, Memorial Culture, Latvian Riflemen, Latvian SS-Legionnaires, First World War, Second World War.

\section{Неудобные герои... Сравнивая мысли о латышских стрелках и легионерах СС в латышской мемориальной культуре 1920-2017 гг.}

\section{Т. Плат}

Для цитирования: Plath T. Uncomfortable Heroes... Comparing thoughts about Latvian Riflemen and SS-Legionnaires in Latvian Memorial Culture 1920-2017 // Вестник Санкт-Петербургского университета. История. 2018. Т. 63. Вып. 2. С. 479-487. https://doi.org/10.21638/11701/spbu02.2018.210

В обеих мировых войнах XX в. значительная часть мужского населения Латвии участвовала в составе специальных латышских подразделений - латышских стрелков в Первой мировой войне и СС-легионеров во Второй. Уже давно назрело описание этих единиц в латышской мемориальной культуре с особым упором на историографию. Несмотря на то что оба подразделения стали неотъемлемой частью истории Латвии, сопоставительный анализ к сегодняшнему дню не был предпринят, что представ-

Tilman Plath - PhD in History, Ernst Moritz Arndt University of Greifswald, 2, Rubenow str., Greifswald, 17487, Federal Republic of Germany; platht@uni-greifswald.de

Тильман Плат - PhD (История), Грайфсвальдский университет им. Э. М. Арндта, Федеративная Республика Германия, 17487, Грайфсвальд, Рубенов штрассе, 2; platht@uni-greifswald.de

(c) Санкт-Петербургский государственный университет, 2018 
ляется чрезвычайно важным и незаменимым, поскольку они воспринимаются нераздельно и почти идеально отражают радикальные повороты истории в Латвии в XX в. Во-первых, естественно, сложилась сугубо «военная» часть исследований - рассказ о храбрых и смелых борцах за национальное дело, лучше всего иллюстрируемый на примере Рождественских битв или Волховских сражений. Во-вторых, и в определенной степени в противоположность первому направлению, освещается вопрос предателей и коллаборационистов, таких как «красные стрелки» или «немецкое пушечное мясо». Наконец, в-третьих, специальные латышские подразделения представляют совершенно необычный резкий и быстрый переход от латышей, изображенных в начале $\mathrm{XX}$ в. антигерманскими левыми социалистами-революционерами, к нацистским правым приспешникам во второй половине века и до сегодняшнего дня.

Ключевые слова: история Латвии, мемориальная культура, латышские стрелки, латышские СС-легионеры, Первая мировая война, Вторая мировая война.

\section{Introduction}

The cases of Latvian Riflemen and the SS-Legionnaires are of particular interest for historical memory of Latvia for at least two reasons. To begin with, the general narrative of Latvian self-image tells a rather peaceful story of Latvia and Latvians, who allegedly lived for 700 hundred years under suppression. A short period of successful and, again, peaceful independence was followed by repeated suppression and occupation, only to be relieved in recent times. A successful Youtube-video "History of Latvia", in which a calm and sympathetic Latvian peasant is incessantly disturbed from the right and the left by foreign aggressors ${ }^{1}$, supports the argument. How can the history of the two rather wellknown, even on the international level, military units of the Riflemen and the Legionaries be integrated into this narrative of innocent and peace-loving Latvian history?

Secondly, although both formations played a significant part in Latvian $20^{\text {th }}$-century history and are well researched, they, at least to my knowledge, have never been researched in a comparative perspective $e^{2}$. This comes as a surprise, given the fact that they are separated by only about 20 years, and, what is more, bear quite a lot of similarities when it comes to some controversial issues regarding their respective histories.

Therefore, the aim is to concentrate on these common features and differences within the historical discussions, mainly, in Latvian historiography. Resting on such an approach,

${ }^{1}$ History of Latvia. URL: https://www.youtube.com/watch?v=EcKIeD3RxRQ (25.01.2018) (accessed 30.03.2018)

2 With regard to the Riflemen, see: Swain G. The Disillusioning of the Revolution's Praetorian Guard: The Latvian Riflemen, Summer-Autumn 1918 // Europe-Asia Studies. 1999. Vol.51. N 4. P.667-686; Vārpa I. Latviešu karavīrs zem Krievijas impērijas, Padomju Krievijas un PSRS karogiem: Latviešu strēlnieki triju vēstures laikmetu griežos. Riga, 2006; Schlürmann J. Vom Zarenadler zum Sowjetstern: Die Lettischen Schützenbataillone- und Regimenter in der Kaiserlich Russischen Armee (1915-1917) // Chakoten. 2006. Bd.61, N 1. S. 19-24; Hartmanis J. Latviešu strēlnieki Ķekavas kaujā 1916. gada martā. Riga, 2012; Ģērmanis U. Oberst Vācietis und die lettischen Schützen im Weltkrieg und in der Oktoberrevolution. Stockholm, 1974; Balcers A. Pulcējaties zem latviešu karogiem. Riga, 2013; Kaimiņš J. Latyšskie strelki v boŕbe za pobedu Oktjabŕskoj Revoljucii: 1917-1918. Riga, 1961; Bērziņš V. Latviešu strēlnieki Pirmajā pasaules karā (1915-1918). Latvijas vēstures mazā bibliotēka. Riga, 2014; Krastinnš J. Latyshskie strelki v bor 'be za sovetskuiu vlast’ v 1917-1920 gg.: vospominanija i dokumenti. Riga, 1962. With regard to the Legionaries see: Ezergailis A. Latviešu legions: varoṇi, nacisti vai upuri? Riga, 1998; Lācis V. Latviešu leg̉ions: Patiesības gaismā. Rīgā, 2006; Silgailis A. Latviešu leğions: Dibināšana, formēšana un kauju gaitas otrā pasaules karā. Rīga, 2001; Vārpa I. Latviešu karavīrs zem kāškrusta karoga: Latviešu legions — nācijas triumfs vai tragēelija? Rīgā, 2003. 
it is necessary to answer the question to what extent the dominant narratives of the Riflemen and Legionnaires have the potential for being used or misused by the respective politics of memory, mainly in Latvia itself, but also in Russia and the West ${ }^{3}$.

Prior to the discussion of common or different issues within the depiction of the histories of both military units, it has to be clarified that the applied understanding of the terms "Riflemen" and "Legionnaires" is not self-evident. Both terms may be used in a broad and in a narrow sense. Following a general approach in Latvian historiography, here "Riflemen" applies to all Riflemen between 1915 and 1920, including the tsarist prerevolutionary ones, as well as the Red and the White Riflemen after the Revolution, significantly smaller in numbers ${ }^{4}$. Notwithstanding this broad approach in the scholarship, there is also a tendency in popular Latvian historical culture to shorten the history of the Riflemen to the early period between 1915-1918 . The term "Legionnaires" in its turn, also following a general tendency, is used in a narrow sense, being applied only to the members of the $15^{\text {th }}$ and $19^{\text {th }}$ Waffen-Grenadier-Divisions of the SS, thereby, excluding other Police Battalions and Auxiliary forces, also organized by the Himmler-led police organs in the Reichskommissariat Ostland ${ }^{6}$. Keeping these definitions in mind, it has to be stated in advance that a lot of misunderstanding and controversies are rooted in divergent perceptions of the terms "Riflemen" and "SS-Legionnaires".

The first, and probably the main issue, while comparing the narratives of the Riflemen and the Legionnaires is a high degree of ambiguity, which caused extremely controversial nature of both discussions. The ambiguity stems from the fact that there is a stereotype of the brave fighter, on the one hand, and the cruel perpetrator, on the other hand, at the same time. It goes without saying that the degree of emphasis on either side depends on the perspective of the respective authors or, broadly speaking, the memorial agency.

\section{Brave Fighters?}

Taking a look at the image of the brave fighter with regard to the Riflemen, it is necessary to consider the battles in Kekava in 1916, with the defense of the so called Death Island as a special lieux de memoires for heroism ${ }^{7}$. But certainly, the Christmas Battle

${ }^{3}$ For politics of memory in Latvia, see: Onken E.-Cl. Revisionismus schon vor der Geschichte: Aktuelle Kontroversen in Lettland um die Judenvernichtung und die lettische Kollaboration während der nationalsozialistischen Besatzung. Galut Nordost Sonderheft 1. Köl, 2003; Wezel K. Geschichte als Politikum: Lettland und die Aufarbeitung nach der Diktatur. Berlin, 2016; Onken E.-Cl. Demokratisierung der Geschichte in Lettland: Staatsbürgerliche Bewusstsein und Geschichtspolitik im ersten Jahrzehnt der Unabhängigkeit. Hamburg, 2003. With special focus on the Riflemen see: Zellis K. Der Erste Weltkrieg und die lettischen Schützen im kollektiven Gedächtnis der Letten // Forschungen zur Baltischen Geschichte. 2015. Bd. 10. S. 163-187. For the general context of Eastern Europe, see: Antlitz der Erinnerung: Geschichtspolitik im Osten Europas. Berlin, 2017.

${ }^{4}$ Latvijas vēsture: 20. gadsimts. 2. papildinātais izdevums / ed. by D. Bleiere. Riga, 2005. L. 69-80.

${ }^{5}$ Hence a new explanatory sign at the former Red Riflemen Place somewhat ironically reads as follows: "This place bears the name in honor of the members of the national formations of the Latvian Riflemen, who participated in the ranks of the Russian Army in the First World War during the years of 1915-1918". See: Explanatory signs added to Rīga's street names // ENG. LSM. LV. September 11, 2015. URL: https://eng.lsm. $\mathrm{lv} /$ article/society/society/explanatory-signs-added-to-rigas-street-names.a145191/ (accessed 25.01.2018).

${ }^{6}$ Latvija Otrajā pasaules karā (1939-1945) / ed. by D. Bleiere. Riga, 2008. L. 29-32.

7 A heroic description of the battle by Klāvs Zarin̦š at: Zarins K. Latviešu strēlnieki 1916. gada kaujās pie K̦ekavas // SARGS. LV. URL: http://www.sargs.lv/Vesture/Vesture/2015/10/26-01.aspx lastcomment (accessed 25.01.2018). 
of early 1917 possesses an extraordinary significance for the image of bravery and boldness of the Latvian Riflemen, which is especially true with regard to the interwar period and the present time. Recent publications about the Death Island and the general fighting during the First World War by Valdis Berziņš and Jānis Hartmanis corroborate this narrative ${ }^{8}$. The foundation of a special museum for the Christmas Battle in 2005 further confirms this notion ${ }^{9}$. Although the effectiveness of the Red Riflemen is not essentially denied, this part of history has certainly faded more into oblivion in recent times ${ }^{10}$. Ironically enough, they were the only military formation under discussion, which actually stood on the victorious side.

The prerevolutionary Riflemen and the Legionnaires, on the other hand, shared unfavorable fate of allegedly heroic, yet defensive battles. Therefore, the equivalent for the Christmas Battle and the Death Island with regard to the Legionnaires appears to have been the Velikaya Battle in March 1944 and the fighting in the Kurland pocket. The link between the Velikaya and the Christmas Battles can be also obviously seen in the fact that both events stipulated the general commemoration days, in honour of the Riflemen - on the $6^{\text {th }}$ January, and in honour of the Legionnaires, as it is well known, - on the $16^{\text {th }}$ March $^{11}$.

\section{War Criminals?}

Whereas the issue of heroism and bravery is quite natural for the depiction of the members of a military unit, the cases of Riflemen and Legionaries are, as it has been mentioned before, of special interest as their narratives also entail the image of cruel perpetrators and sadistic executers. Understandably, this image is portrayed from the outside perspective. Consequently, the Riflemen and Legionnaires not only found themselves during the actual fighting in a defensive position, but also faced an onslaught on their reputation in the aftermath. This especially concerns the Legionnaires and their alleged participation in the Holocaust and other atrocities, such as the anti-partisan warfare under German rule in Eastern Europe ${ }^{12}$. To proof the opposite is clearly the main aim of a number of related publications by authors like Ezergailis, Silgailis or Lācis, who starts one of his publications with the following remark: "Why did this book need to be written? First, to counter allegations of war crimes against Latvian soldiers during the Second World War"13.

This paper does not claim to offer a final answer to this matter. On the contrary, it treats the debate itself as a historical phenomenon. As a matter of fact, these accusations

${ }^{8}$ Bērziniš V. Latviešu strēlnieki Pirmajā pasaules karā (1915-1918). Latvijas vēstures mazā bibliotēka. Riga, 2014; Hartmanis J. Latviešu strēlnieki Ķekavas kaujā 1916. gada martā. Riga, 2012.

${ }^{9}$ Latvijas Kara Muzejs. URL: http://www.karamuzejs.lv/lv/zm.aspx (accessed 25.01.2018).

10 Zellis K. Der Erste Weltkrieg und die lettischen Schützen im kollektiven Gedächtnis der Letten // Forschungen zur Baltischen Geschichte. 2015. Bd.10. S. 164.

${ }^{11}$ Neiburgs U. 1944. gada 16. marts un tā atspogu)ojums vēstures literatūrā // Karojošā Piemiņa: 16. Marts un 9. Maijs / ed. by N. Muižnieks, V.Zelče. Riga, 2011. L. 75-91; Zelče V. Latviešu leǵiona pieminas dienas genēze un leǵionāru komemorācijas tradīcija Rietumu latviešu kopienā // Ibid. L. 92-122; Zellis K. Der Erste Weltkrieg... S. 174.

${ }^{12}$ Bjarke W. B. The debate on the Latvian SS Volunteer Legion // Baltic Defence Review. 2000. Vol.3. P. $103-114$.

${ }^{13}$ Lācis V. The Latvian Legion According to Independent Observers. Riga, 2006. P. 5. See also: Ezergailis A. Nazi/soviet Disinformation about the Holocaust in Nazi-occupied Latvia: Daugavas Vanagi: Who are they? Revisited. Riga, 2005. 
predominantly come from outside Latvia, or at least from a non-Latvian surrounding, mainly, within a Russian context, and sometimes from the West. The most notorious example is Michail Krysin and his book about the Latvian Legion ${ }^{14}$. As it has already been said, more often than not, confusion stems from misunderstandings concerning the term "Legionnaires", which is more associated with war crimes due to the inclusion of various police battalions than the narrower definition of the Legion and its soldiers. However, in Latvian literature personal overlapping between Police battalions and the Legion, founded in 1943, is considerably downplayed, or, at times, like in Lācis' writings, the question of Antisemitism among the Legionaries is not raised at all. Instead, much emphasis is placed on the effort to defend oneself from Soviet allegations of committed war crimes by, for example, Ezergailis, deliberately not taking account of the cold war context of such argumentation. ${ }^{15}$.

When speaking about the Riflemen respectively, the problem of committed war crimes seems to be much less urgent. However, especially with regard to the Red Riflemen, the issue of terror during the Civil War arises, not the least when observing individuals and their careers in the Soviet institutions of repressions, such as the Cheka and the forerunner of the Gulag, which are closely connected with such names as Jēkabs Peterss, Teodors Eihmans, Jānis Berziņš or Mārtiņ̌̌ Lācis Sudrabs ${ }^{16}$. Again, naturally, the main accusations come from outside Latvia, as, for example, in a quote by Solzhenitsyn: "The Estonians and Lithuanians are close to my own soul... They never harmed anyone, lived quietly, in good conditions, morally more honestly than we. As it turned out, they were guilty of living next to us and cutting us off from the sea... As for Latvians, my attitude is somewhat more complicated. There is an element of fate. It was they, after all, who started the whole thing" 17 .

\section{National Heroes?}

Besides the controversial debate about the heroic or criminal deeds of the respective soldiers, a similarly controversial discussion revolves around the questions of the ideological goals of the fighters, which has a special importance within the national framework. Were the Riflemen and the Legionnaires Latvian freedom fighters?

As far as the Riflemen are concerned, it is safe to say that an affirmative stance towards the raised question seems very problematic. The prerevolutionary Riflemen were fighting for the Tsar, and an autonomous Latvia did not exist at the time, not even as an administrative unit by this name. Although it is certain, as it was repeatedly emphasized in Interwar Latvia and today, they undoubtedly defended their homeland against the arch enemy, the Germans. Concerning the Red Riflemen, it is even more awkward since they even attacked the newly founded Latvian state in late 1918, and early 1919. Also, the white Riflemen battalions Troitsk and Imanta hardly defended Latvian independence in the

${ }^{14}$ Krysin M. Ju. Latyshskii legion SS: Vchera i segodnia. Istoriia na ustakh. Moscow. 2006; Gräfe K.-H. Vom Donnerkreuz zum Hakenkreuz: Die baltischen Staaten zwischen Diktatur und Okkupation. Berlin, 2010; Krysin M. Ju. Pribaltiiskii fashizm. Istoriia i sovremennost'. Moscow, 2007.

15 Lumans V. O. Latvia in World War II / $1^{\text {st }}$ ed. N 11. New York, 2006.

16 Gorchakov O. A. Jan Berzin. Komandarm GRU. St. Petersburg, 2004.

17 Gordon F. Latvians and Jews between Germany and Russia. Stockholm, 1990. P.27; Zellis K. Der Erste Weltkrieg und die lettischen Schützen im kollektiven Gedächtnis der Letten // Forschungen zur Baltischen Geschichte. 2015. Bd. 10. S. 171. 
Urals and Siberia, serving the White Russian movement, which fought for an undivided Russia. However, as Kaspars Zellis has shown, the Latvian Interwar narrative and recent literature has tried hard to construct an inclusive narrative of all Riflemen, incorporating them into a single story of national Liberation War. Even the Red Riflemen supported Latvian National Independence, as it was argued, since by fighting the Russian White Movement, the Red Riflemen prevented them from implementing their ideas of an undivided Russia, in which an independent Latvia could barely have existed. The inclusive character of the narrative is visually expressed at the entrance of the Brethren Cemetery in Riga with the inscription bearing the years of 1915-1920, which obviously implies a common fight for national independence by Prerevolutionary Riflemen, Soldiers of the newly founded National Army and Post-Revolutionary Riflemen. The commitment of the former Riflemen officers Andrejs Auzāns and Rūdolfs Bangerskis, who fought on different sides in the Russian Civil War and , therefore, did not take part in the Liberation Wars on Latvian soil, led to an integration of Latvian Riflemen into the commemoration of a general national struggle for independence. The introduction of the already mentioned commemoration day on $6^{\text {th }}$ January and the foundation of a Society of Latvian Old Riflemen served this very purpose ${ }^{18}$.

The case of the Legionnaires is by no means less problematic. Generally speaking, one may assert that the situation resembles the prerevolutionary Riflemen, to a certain extent, for under German occupation the question of independent Latvia was also off limits. Hence, at best the Legionnaires defended their homeland, once again against their arch enemy, this time, the Soviets, perceived as Russians. A significant difference, though, is manifested by the degree of voluntariness, although, ironically enough, it were the SS-Divisions that had the label "voluntary", notwithstanding their actual character. The remarkable percentage of desertions and the fact that roughly $1 / 3$ of the mobilized population did not show up at the German conscription offices, gives us a hint of the extent of voluntariness among Latvian male population, which is estimated by Inesis Feldmanis as being at about 15-20 percent ${ }^{19}$. It is not so surprising, considering that a large number of Latvian society understood very well that the Legionnaires served as German cannon fodder in the first place. Nevertheless, as Uldis Neiburgs has described it, disliking the Germans but fearing the Russians, many Latvians saw no better alternative than fighting with the Germans $^{20}$. All the more so, when keeping in mind that the events of the First World War and the Riflemen themselves served as a blue print for the idea of the formation of national armed forces.

\section{Personal adaptability}

Since the time gap between the the Riflemen and Legionnaires was rather small, a natural question of personal transformation of the soldiers of the Riflemen into the Legionnaires arises. But due to the obvious fact that both were fighting units, consisting of

18 Zellis K. Der Erste Weltkrieg... S. 174.

19 Feldmanis I. Latvija Otrajā pasaules karā (1939-1945): Jauns konceptuāls skatijums. Latvijas vēstures mazā bibliotēka. Riga, 2012. L. 67.

${ }^{20}$ Neiburgs U. Rietumu sabiebroto tēls Latvijā nacistiskās Vācijas okupācijas laikā: oficiālā propaganda un sabiedrības noskaņojums 1941-1945 // Okupācijas režīmi Latvijā 1940.-1959. gadā: Latvijas Vēsturnieku komisijas 2002. gada pētijumi (2002) / ed. by A. Caune. Riga, 2004. L. 182. 
young men, the period of roughly 20 years was sufficient to have changed the ranks. Also, about 12000 former Red Riflemen remained in Soviet Russia where, as it is well known, a large part became victims of the purges in 1937/38. But at least some cases deserve to be mentioned: among them, the already mentioned Rüdolfs Bankerskis probably the most famous one, who fought against the Red Riflemen in the Russian Civil war, later became General Inspector of the Latvian Legion under German occupation, which certainly is the most prominent example of personal continuity between the two formations ${ }^{21}$.

A second, rather famous, example of, at least, a connection between white Riflemen and Legionnaires is Kārlis Lobe, who fought for Alexander Kolčak during the Civil War and later became officer in the $19^{\text {th }}$ Waffen Grenadier Division of the SS. Likewise, he may serve as an example of the personal adaptability of war criminals of Latvian Police battalions and the Legion since he participated in mass shooting of Jews in 1941 and in anti-partisan purges in $1943^{22}$.

Finally, and less known, is the case of Pēteris Lapainis, who was extraordinary due to the fact that he served among the tsarist Riflemen, within the Red Riflemen battalions, the newly founded Latvian army and also in the Legion. Moreover, he was awarded with military decorations in all four military units. Unfortunately, his case hasn't been fully researched yet, so little is known about his politically alignments during these years ${ }^{23}$.

\section{Conclusion}

After discussing the key issues of the narratives of the Riflemen and Legionnaires, it seems appropriate to outline possible uses or misuses of these issues. Again, whether the term "use" or "misuse" seems suitable, depends on the respective perception. This consideration notwithstanding, the following generalizations may be made: both the Riflemen and the Legionnaires have been used/misused in Latvian historiography for the reinforcement and simplification of the national narrative, neglecting the above mentioned contradictory elements. However, in the external depiction of the Riflemen and Legionnaires often an undue emphasis has been put on violent and criminal aspects of the history of the Riflemen and Legionnaires.

To avoid such uses/misuses, a decisive escape from the vicious cycle of accusation, apology or vindication, exclusively within national framework, is needed. Such an escape may be successful if the scope is broadened, either in geographical or chronological dimension. With regard to the geographical dimension, it would be productive to analyse the Riflemen's case in the framework of a general imperial strategy of national mobilization on both sides of the Eastern Front. Why, for example, the Czechoslovakian Legion switched sides and fought for the Whites, while the allegedly anti-German Riflemen stood firm as Lenin's Praetorian guards after Brest-Litowsk? Admittedly, although the motives and the mood of the Red Riflemen in 1918 have been analysed by Geoffrey Swain, this top-

21 Vārpa I. Latviešu karavīrs zem Krievijas...

22 Urtāns A. Ebreju tautības civiliedzīvotāju slepkavošana Kuldīgas apriṇkīi // Holokausts Latvijā: Starptautiskās konferences materiāli, 2004. gada 3.-4. jūnijs, Rīga, un 2004.-2005. gada pētījumi par holokaustu Latvijā / ed. by D. Ērglis. Latvijas Vēsturnieku Komisijas raksti Sējums, vol. 18. Riga, 2006. L. 124; Kangeris K. Latviešu policijas bataljoni lielajās partizānu apkarošanas akcijās 1942. un 1943. Gadā // Totalitārie okupācijas režīmi Latvijā 1940.-1964. gadā: Latvijas Vēsturnieku komisijas 2003. gada pētijumi / ed. by D. Ërglis. Latvijas Vēsturnieku Komisijas raksti. Vol. 13. Rīga, 2004. L. 345.

${ }_{23}$ Šēnbergs M. Lāčplēša Kara ordena kavalieri: biogrāfiska vārdnīca. Rīga. 1995. L. 296. 
ic (the Red Riflemen) is, not surprisingly, researched outside Latvia ${ }^{24}$. Thinking about the broader framework of the Legionnaires, the fact of other Non-German SS-Units has been mentioned by Inesis Feldmanis, but not deeply researched in a comparative approach ${ }^{25}$. First steps to a contextualized history of the SS-mobilization efforts, in the Baltics at least, have been made by Matthew Kott, again a Non-Latvian ${ }^{26}$.

Finally, with regard to the chronological dimension, it seems to be a promising undertaking to take Vejas Liulevičius' study on the German soldiers on the Eastern front in World War I as a model, because it highlights the impact of the collective memory of former soldiers on post war society, which eventually led, among other reasons, of course, to the second war, which he labels "the hidden heritage of the Eastern front in the German case" $^{27}$. A similar approach to the Riflemen would help us better understand the complexity of Latvian interwar society and the impact of the Soviet or Civil War Experience on it, and would lead to a deeper understanding of the apparent shift in Latvian society, with its members' transformation from convinced socialists to nationalists within just one generation, also, including the Generation of the Legionnaires within a similar approach.

\section{References}

Antlitz der Erinnerung: Geschichtspolitik im Osten Europas. Berlin, Berliner Wissenschafts-Verlag Publ., 2017, 1741.

Balcers A. Pulcējaties zem latviešu karogiem. Riga, Biedrība "Vilki“; Apgāds „Zelta grauds“ Publ., 2013, 4151.

Bērzinšš V. Latviešu strēlnieki Pirmajā pasaules karā (1915-1918). Latvijas vēstures mazā bibliotēka. Riga, Latvijas Universitāte Press, 2014, 1031.

Bjarke W. B. The Debate on the Latvian SS Volunteer Legion. Baltic Defence Review, 2000, vol. 3, pp. 103-14.

Ezergailis A. Latviešu leǵions: varoṇi, nacisti vai upuri? Riga, Latvijas Vēstures Institūta Apgāds Press, 1998, 1231 .

Ezergailis A. Nazi/soviet Disinformation about the Holocaust in Nazi-occupied Latvia: Daugavas Vanagi: Who are they? Revisited. Riga, Latvijas 50 gadu okupacijas muzeja fonds Publ., 2005, 215 p.

Feldmanis I. Latvija Otrajā pasaules karā (1939-1945): Jauns konceptuāls skatījums. Latvijas vēstures mazā bibliotēka. Rìgā, LU Akadēmiskais apgāds Press., 2012, 97 l.

G̦ērmanis U. Oberst Vācietis und die lettischen Schützen im Weltkrieg und in der Oktoberrevolution. Stockholm, Almqvist \& Wiksel Print., 1974, 336 S.

Gorchakov O.A. Jan Berzin. Komandarm GRU. St. Petersburg, Izdatel'ski dom "Neva” Publ., 2004, 186 p. (In Russian)

Gordon F. Latvians and Jews between Germany and Russia. Stockholm, Memento Publ., 1990. 66 p.

Gräfe K.-H. Vom Donnerkreuz zum Hakenkreuz: Die baltischen Staaten zwischen Diktatur und Okkupation. Berlin, Organon Publ., 2010, 511 S.

Hartmanis J. Latviešu strēlnieki K,ekavas kaujā 1916. gada martā. Riga, Jumava Publ., 2012, 2081.

Kaimiņš J. Latysskie strelki v boŕbe za pobedu Oktjabrskoj Revoljucii: 1917-1918. Riga, Latviiskoe gosudarstvennoe izdatel'stvo Publ., 1961, 421 p. (In Russian)

Kangeris K. Latviešu policijas bataljoni lielajās partizānu apkarošanas akcijās 1942. un 1943. gadā. Totalitārie okupācijas režími Latvijā 1940.-1964. gadā: Latvijas Vēsturnieku komisijas 2003. gada pētījumi, Lat-

24 Swain G. The Disillusioning...

${ }^{25}$ Feldmanis I. Latvija Otrajā pasaules... L. 64.

${ }^{26}$ Kott M. Rekrutierung der Waffen-SS im Reichskommissariat Ostland: der Versuch einer schwer fassbaren Synthese // Reichskommissariat Ostland: Tatort und Erinnerungsobjekt: eine Publikation des Instituts für schleswig-holsteinische Zeit- und Regionalgeschichte der Universität Flensburg und des Militärgeschichtlichen Forschungsamtes / Hrsg. S. Lehmann, R. Bohn, U.Danker. Zeitalter der Weltkriege. Bd. 8. Paderborn, 2012. S. 117-146

${ }^{27}$ Liulevicius V.G. War land on the Eastern front: Culture, national identity and German occupation in World War I. Cambridge, 2005. 
vijas Vēsturnieku Komisijas raksti, vol. 13. Ed. by D.Ērglis. Riga, Latvijas Vēstures Instituta Apgāds Press., 2004, 1l. 332-357.

Kott M. Rekrutierung der Waffen-SS im Reichskommissariat Ostland: der Versuch einer schwer fassbaren Synthese. Reichskommissariat Ostland: Tatort und Erinnerungsobjekt: eine Publikation des Instituts für schleswig-holsteinische Zeit- und Regionalgeschichte der Universität Flensburg und des Militärgeschichtlichen Forschungsamtes, Zeitalter der Weltkriege, Bd. 8. Hrsg. S. Lehmann, R. Bohn, U. Danker. Paderborn, Schöningh Publ., 2012, S. 117-146.

Krastiņš J. Latysskie strelki v bor'be za Sovetskuju Vlast' v 1917-1920 gg.: vospominanija i dokumenti. Riga, Izdatel'stvo Akademii nauk Latviǐskoĩ SSR Press., 1962, 526 p. (In Russian)

Krysin M. Ju. Latyshskii legion SS: Vchera i segodnia. Moscow, Veche Publ., 2006, 284 p. (In Russian)

Krysin M. Ju. Pribaltijskij fašizm: Istorija i sovremennost. Moscow, Veche Publ., 2007, 570 p. (In Russian)

Lācis V. Latviešu legions: Patiesības gaismā. Rīgā, Jumava Publ., 2006, 275 l.

Lācis V. The Latvian Legion According to Independent Observers. $2^{\text {nd }}$ updated ed. Riga, Jumava Publ., 2006, $66 \mathrm{p}$.

Liulevicius V.G. War land on the Eastern front: Culture, National Identity and German Occupation in World War I. Cambridge, Cambridge University Press, 2005, 309 p.

Lumans V. O. Latvia in World War II. $1^{\text {st }}$ ed. New York, Fordham University Press, 2006, 547 p.

Neiburgs U. 1944. gada 16. marts un tā atspogu)ojums vēstures literatūrā. Karojošā Pieminga: 16. marts un 9. maijs. Eds N. Muižnieks, V.Zelče. Riga, Zinātne Publ., 2011, 11. 75-91.

Neiburgs U. Rietumu sabiebroto tēls Latvijā nacistiskās Vācijas okupācijas laikā: oficiālā propaganda un sabiedrības noskanojums 1941-1945. Okupācijas režìmi Latvijā 1940.-1959. gadā: Latvijas Vēsturnieku komisijas 2002. gada pètījumi (2002). Latvijas Vēsturnieku komisijas raksti Symposium of the Commission of the Historians of Latvia, vol. 10. Ed. by A. Caune. Rìga, Latvijas vēstures institūta apgāds Press., 2004, 11. 169-215.

Onken E.-Cl. Revisionismus schon vor der Geschichte: Aktuelle Kontroversen in Lettland um die Judenvernichtung und die lettische Kollaboration während der nationalsozialistischen Besatzung. Köln, Verlag Wissenschaft und Politik Publ., 2003, 131 S.

Onken E.-Cl. Demokratisierung der Geschichte in Lettland: Staatsbürgerliche Bewusstsein und Geschichtspolitik im ersten Jahrzehnt der Unabhängigkeit. Hamburg, Krämer Publ., 2003, 294 S.

Schlürmann J. Vom Zarenadler zum Sowjetstern: Die Lettischen Schützenbataillone- und Regimenter in der Kaiserlich Russischen Armee (1915-1917). Chakoten, 2006, Bd. 61, no. 1, S. 19-24.

Šēnbergs M. Lāčplēša Kara ordeņa kavalieri: biogrāfiska vārdnīca. Rīga, Latvijas Valsts vēstures arhīvs: Jāna sèta Publ., 1995, 613 l.

Silgailis A. Latviešu leǵions: Dibināšana, formēšana un kauju gaitas otrā pasaules karā. Rīga, Junda Publ., 2001, 3561.

Swain G. The Disillusioning of the Revolution's Praetorian Guard: The Latvian Riflemen, Summer-Autumn 1918. Europe-Asia Studies, 1999, vol. 51, no. 4, pp. 667-686.

Urtāns A. Ebreju tautības civiliedzìvotāju slepkavošana Kuldīgas apriṇkī. Holokausts Latvijā: Starptautiskās konferences materiāli, 2004. gada 3. - 4. jūnijs, Rīga, un 2004.-2005. gada pētījumi par holokaustu Latvijā, Latvijas Vēsturnieku Komisijas raksti Sējums, vol. 18. Ed. by D. Ërglis. Rīga, Latvijas Vēstures institūta Apgāds Press., 2006, 1l. 118-136.

Vārpa I. Latviešu karavīrs zem kāškrusta karoga: Latviešu legions - nācijas triumfs vai tragèdija? Rīgā, Nordik Publ., 2003, 623 l.

Vārpa I. Latviešu karavīrs zem Krievijas impērijas, Padomju Krievijas un PSRS karogiem: Latviešu strēlnieki triju vēstures laikmetu griežos. Rīgā, Nordik Publ., 2006, 7261.

Wezel K. Geschichte als Politikum: Lettland und die Aufarbeitung nach der Diktatur. Berlin, Berliner Wissenschafts-Verlag Publ., 2016, 326 S.

Zelče V. Latviešu leǵiona piemiņas dienas genēze un leǵionāru komemorācijas tradīcija Rietumu latviešu kopienā. Karojošā Piemiṇa: 16. Marts un 9. Maijs. Eds N. Muižnieks, V.Zelče. Riga, Zinātne Publ., 2011, 1l. 92-122.

Zellis K. Der Erste Weltkrieg und die lettischen Schützen im kollektiven Gedächtnis der Letten. Forschungen zur Baltischen Geschichte, 2015, Bd. 10, S. 163-87.

Received: 30.01 .2018

Accepted: 30.03 .2018 